\title{
A CARACTERIZAÇÃO DAS REGIÕES METROPOLITANAS CATARINENSES E O ESTATUTO DA METRÓPOLE
}

\author{
Sergio Torres Moraes ${ }^{1}$ \\ Antonio Guarda ${ }^{2}$ \\ Gabriela Stein Zacchi ${ }^{3}$
}

\begin{abstract}
Resumo: Caracterizar Regiões Metropolitanas solicita uma organização abrangente, envolvendo diversos municípios numa dinâmica elaborada. No Brasil, para atender a essa solicitação, foi aprovado em 2015 o Estatuto da Metrópole, uma lei federal que estabelece critérios mais rigorosos para a instituição de Regiões Metropolitanas do que os existentes até então. Buscamos entender aqui em que medida a caracterização atual das Regiões Metropolitanas de Santa Catarina se contrapõe aos critérios de caracterização sugeridos pelo Estatuto da Metrópole. Este estudo parece indicar que a adoção dos critérios estabelecidos no Estatuto da Metrópole é um bom ponto de partida para evitar a pasteurização de unidades territoriais, o que pode trazer dificuldades na gestão e a eleição de prioridades para o planejamento territorial.
\end{abstract}

Palavras-chave: Regiões Metropolitanas; Estatuto da Metrópole; Santa Catarina; Gestão Territorial

\section{THE CHARACTERIZATION OF THE METROPOLITAN REGIONS OF SANTA CATARINA AND THE METROPOLIS STATUTE}

\begin{abstract}
Metropolitan Regions' characterization requires a comprehensive organization, involving several municipalities in a complex dynamic. In Brazil, to meet this goal, the Metropolis Statute, a federal law that establishes more rigorous criteria for the establishment of Metropolitan Regions than former laws, was approved in 2015. In this paper we discuss the current characterization of the Metropolitan Regions of Santa Catarina face up to the characterization criteria suggested by the Statute of the Metropolis. This comparison seems to indicate that the adoption of the criteria established by the Metropolis Statute is a good starting point to avoid the pasteurization of territorial units, which can cause difficulties in the management and the selection of priorities for territorial planning.
\end{abstract}

Keywords: Metropolitan Regions; Metropolis Statute; Santa Catarina; Territorial Management

\footnotetext{
${ }^{1}$ Professor Doutor da Universidade Federal de Santa Catarina no curso de Arquitetura e Urbanismo. Contato: sergiomoraes@arq.ufsc.br

${ }^{2}$ Doutorando em Arquitetura e Urbanismo da Universidade Federal de Santa Catarina. Coordenador Estadual de Base Territorial em Santa Catarina no IBGE. Contato: antonio.guarda@posgrad.ufsc.br

${ }^{3}$ Mestranda em Arquitetura e Urbanismo da Universidade Federal de Santa Catarina. Pesquisadora da Agência de Coordenação de Aperfeiçoamento de Pessoal de Nível Superior - CAPES. Contato:

gabriela.zacchi@posgrad.ufsc.br
} 


\section{LA CARACTERIZACIÓN DE LAS REGIONES METROPOLITANAS CATARINENSES Y EL ESTATUTO DE LA METROPOLE}

Resumen: La caracterización de las Regiones Metropolitanas requiere una organización integral que involucre a varios municipios en una dinámica compleja. En Brasil, para alcanzar este objetivo, el Estatuto de Metrópolis, una ley federal que establece criterios más rigurosos para el establecimiento de las Regiones Metropolitanas que las leyes anteriores, fue aprobado en 2015. En este trabajo discutimos la caracterización actual de las Regiones Metropolitanas de Santa Catarina frente a los criterios de caracterización sugeridos por el Estatuto de la Metrópoli. Esta comparación parece indicar que la adopción de los criterios establecidos por el Estatuto de Metrópolis es un buen punto de partida para evitar la pasteurización de las unidades territoriales, lo que puede ocasionar dificultades en la gestión y la selección de prioridades para la planificación territorial.

Palabras clave: Regiones Metropolitanas; Estatuto de la Metrópolis; Santa Catarina; Gestión Territorial

\section{INTRODUÇÃO}

Ao longo da segunda metade do século XX ocorreu uma elevação acentuada dos índices de urbanização em todo o mundo. Essa fase de expansão das cidades correspondeu também a uma extraordinária valorização das áreas centrais como jamais havia acontecido em épocas anteriores. Nas últimas três décadas, entretanto, observa-se uma inversão desse panorama com a descentralização e dispersão dos núcleos urbanos e com a redução do poder polarizado de áreas centrais em cidades de grande e médio porte (REIS FILHO, 2006). Como consequência, surgiram sistemas urbanos com formas mais complexas que necessitam de estratégias de estudo e planejamento mais articuladas, como, por exemplo, as regiões metropolitanas.

A dispersão urbana, em especial a das metrópoles e suas faixas envoltórias, configurase hoje como um território que solicita uma organização abrangente, envolvendo diversos municípios e diversas disciplinas, numa dinâmica elaborada e políticas públicas complexas. No Brasil, para tentar atender a essa solicitação e dar forma legal para as demandas de integração, surge o Estatuto da Metrópole - lei Federal nº 13.089 aprovada em 2015 - que estabelece diretrizes gerais para o planejamento, a gestão e a execução das funções públicas de interesse comum em regiões metropolitanas e em aglomerações urbanas, bem como determina normas gerais para a elaboração de um Plano de Desenvolvimento Urbano Integrado (PDUI) e outros instrumentos de governança interfederativa.

A ideia de transcender as fronteiras municipais para o planejamento urbano tende a focar na racionalização de recursos, sejam eles ambientais, econômicos ou sociais, como 
principal motivador. Não obstante, há a dificuldade na conceituação, classificação, e mesmo apreensão da região metropolitana e de sua atual forma mutante, uma vez que o próprio conceito de região pode ser apropriado em diferentes escalas. Reflexo dessa limitação é que, muito embora a aprovação do Estatuto da Metrópole tenha representado um grande avanço rumo à gestão interfederativa, até o momento não foi possível identificar a aplicação efetiva da nova lei.

Uma das causas deste hiato entre a aprovação da lei e o efetivo exercício do planejamento regional integrado parece ser a dificuldade de delimitação do objeto a ser regulamentado - as metrópoles, aglomerações urbanas e microrregiões (ZIONI E MENCIO, 2017; HOSHINO E MOURA, 2015; RIBEIRO, SANTOS JÚNIOR E RODRIGUES, 2015). Alguns dos autores consultados reforçam a inconstitucionalidade do Estatuto da Metrópole enquanto delimitador das regiões metropolitanas, sendo que tal instituição já é atribuição dos estados. Outros, em contrapartida, comemoram o estabelecimento de critérios para a definição das regiões metropolitanas, coibindo assim sua proliferação casuística.

Na investida de colaborar para essa discussão de base, neste estudo serão mostrados dois cenários para as Regiões Metropolitanas (RMs) de Santa Catarina: o atual, onde elas foram instituídas por critérios políticos do governo estadual; e um cenário hipotético, onde as RMs seriam instituídas baseadas nos critérios do Estatuto da Metrópole, que tem sua base nas definições estabelecidas pelo IBGE - Instituto Brasileiro de Geografia e Estatística. Assim, procuramos entender em que medida as características formativas das Regiões Metropolitanas de Santa Catarina afetam as políticas públicas nesses arranjos territoriais tão específicos.

\section{Desenvolvimento}

\section{O Estatuto da Metrópole}

Milton Santos ao discorrer sobre a urbanização brasileira destaca que ela se tornou praticamente generalizada a partir do terceiro terço do século XX, e que atualmente a fase é de macrourbanização e metropolização. Nessa fase, o turbilhão demográfico e a terceirização são fatos notáveis. Registra-se, todavia, uma atenuação relativa das "macrocefalias", pois, além das cidades milionárias, desenvolvem-se cidades intermediárias ao lado de cidades

\footnotetext{
${ }^{4}$ Santos (2009) conceitua "macrocefalia" como a concentração massiva das atividades econômicas que propícia o desencadeamento de processos descompassados como o redirecionamento e convergência de fluxos migratórios, o déficit no número de empregos, ocupação desordenada de determinadas regiões da cidade e a estigmatização de estratos sociais.
} 
locais, todas, porém, adotando um modelo geográfico de crescimento espraiado, com um tamanho desmesurado que é causa e efeito da especulação (SANTOS, 2009).

As metrópoles são, portanto, entidades legítimas que nasceram com a produção social do espaço no capitalismo, passaram pelas formas de sua estruturação funcional e espacial, mas que no Brasil ainda não chegaram às formas de intervenção sobre esta estruturação, por meio do planejamento e da gestão, especialmente pelo poder público. Assim, há um déficit político na capacidade das cidades-regiões de realizarem um planejamento urbano ativo. Como as regiões metropolitanas (onde os problemas e oportunidades se apresentam) não coincidem com as regiões político-institucionais estabelecidas no Brasil, a gestão territorial se torna indefinida aumentando a degradação ambiental, a falta de saneamento básico, o desemprego e a carência de infraestrutura urbana (MARICATO, 2011).

A reticência brasileira em relação ao planejamento urbano regional não surgiu ao acaso, o país tem um contexto político que valoriza a autonomia municipal para a tomada de decisões. O federalismo brasileiro, que sucedeu regime militar, teve como foco a defesa da descentralização, em especial o reforço ao municipalismo. Tal contexto político do país valorizou a autonomia municipal para a tomada de decisões. Essa autonomia foi legitimada com a Constituição Federal de 1988 e com a aprovação do Estatuto da Cidade em 2001, que reforça a autonomia dos municípios nas decisões de ordenamento do território urbano.

É importante notar que no contexto da ditadura militar, entre 1964 e 1984, o país deixou de ser predominantemente rural para ter a maior parte da população nas cidades - com um crescimento urbano desordenado e promotor de desigualdades socioambientais (BOEIRA, 2004). Em reação a esse fato, o então governo ditatorial cria um aparato visando o desenvolvimento das cidades brasileiras. Maricato (2011) explana que o II Plano Nacional de Desenvolvimento (PND) de 1974, que instituiu a criação do Serviço Federal de Habitação e Urbanismo, posteriormente sucedido pela Comissão de Política Urbana e Regiões Metropolitanas, alavancou um período em que o Planejamento Urbano ganhou muito prestígio e os Planos Diretores se multiplicaram, fomentados por incentivos do governo federal. A despeito da estrutura criada e dos investimentos realizados pelo governo militar, o destino das cidades não se alterou de forma significativa. Ainda assim, Maricato (2011) afirma que a atuação do Estado nesse período mostrou-se mais efetiva do que nas décadas seguintes, marcadas pela desregulamentação das políticas públicas e pelo recuo nos investimentos. 
Cabe lembrar, que já a partir de 1930, com a chegada ao país do novo modelo industrial estabelecido pelas Revoluções Industriais Europeias, foram desencadeadas políticas de estado intervencionistas de maior e menor escalas sem, contudo, coibir o surgimento dos cartéis e oligopólios e o agravamento das crises social, política, econômica e ambiental nas áreas de concentração urbana (BOEIRA, 2004).

Referenciado em experiências de países como Inglaterra e França, começa a emergir no Brasil da virada do milênio a consciência de que um planejamento integrado de toda a região metropolitana é desejável. Mencio e Zioni (2017) elencam esforços empreendidos neste âmbito pelo Ministério da Integração Nacional, que em 2006 elaborou um documento base para a definição da Política Nacional de Ordenamento Territorial (PNOT). Este documento incentiva a ação coordenada dos diferentes níveis do governo no território. As autoras acrescentam:

Especialmente com relação às regiões metropolitanas, e dentre as várias estratégias indicadas para estruturação de um sistema de governança territorial, o PNOT citava a necessidade de promover a integração das múltiplas escalas (municipal, microrregional, mesorregional, estadual, macrorregional e continental) nas políticas de ordenamento territorial. E, ainda mais, indicava o fortalecimento da gestão integrada das regiões metropolitanas com dotação orçamentária específica (MENCIO e ZIONI, p.12, 2017).

Em consonância com este movimento, em janeiro de 2015 foi sancionada a Lei 13.089, o Estatuto da Metrópole, que estabelece diretrizes gerais para o planejamento, a gestão e a execução das funções públicas de interesse comum em regiões metropolitanas e em aglomerações urbanas instituídas pelos estados. Normatiza ainda o plano de desenvolvimento urbano integrado e outros instrumentos de governança interfederativa. A Lei Federal estipulou o prazo de janeiro de 2018 para que todas as metrópoles, aglomerados urbanos e microrregiões já anteriormente instituídas pelos estados estejam com seus Planos de Desenvolvimento Urbano Integrado (PDUI) prontos e elaborados com a participação popular, para, a partir de então, todos os Planos Diretores Municipais se adequarem aos preceitos estabelecidos em conjunto. O que se vê, entretanto, é que pouco movimento foi feito pelos estados e municípios no sentido de atender à legislação. Mesmo passados os três anos de prazo originalmente estabelecido, nenhuma região metropolitana brasileira está com o Plano de Desenvolvimento Urbano Integrado aprovado, provocando o adiamento da data limite para finalização dos PDUIs para dezembro de 2021.

Esta flexibilização do prazo escusa-se no pretexto de que o Estatuto da Metrópole não definiu claramente os critérios a serem empregados para a elaboração dos PDUIs, nem as 
estruturas organizacionais das políticas envolvidas em cada processo, não sendo possível dessa maneira punir os responsáveis pelo atraso. Outra grande dificuldade percebida na sua implementação é a necessidade de abrir mão da autonomia já arraigada entre os entes da federação. Ou seja, é um problema de ordem política (NETO e ALVES, 2016; DE SÁ, 2017).

A percepção destas lacunas na redação do Estatuto da Metrópole levou a Subcomissão de Governança Metropolitana da Câmara dos Deputados a apresentar, em 05 de outubro de 2016, várias sugestões de alterações à lei buscando facilitar a aplicabilidade do novo Estatuto. Dentre as diversas recomendações, chama a atenção a recomendação de rever o veto à criação do Fundo Nacional de Desenvolvimento Integrado. O fundo, vetado no ato de sanção do Estatuto da Metrópole, é considerado pela Subcomissão de Governança Metropolitana o instrumento mais importante e necessário à promoção de desenvolvimento de unidades territoriais e a consequente diminuição das desigualdades regionais.

O Estatuto da Metrópole também faz menção ao Sistema Nacional de Desenvolvimento Urbano (SNDU), que deveria concentrar as informações metropolitanas como dados estatísticos, cartográficos, ambientais, geológicos e outros relevantes para o planejamento, mas, às vésperas de acabar o prazo original para a elaboração dos PDUI, o SNDU ainda não havia sido implementado pela união.

A maior polêmica, entretanto, versa sobre o Estatuto da Metrópole estar se sobrepondo a direitos já adquiridos pelos municípios e pelos estados a partir da Constituição Federal de 1988. A dificuldade de orquestrar as responsabilidades políticas para o ordenamento do território metropolitano e regional esbarra na própria definição do objeto a ser regulamentado pela respectiva lei. Até 2015, a competência de criar regiões metropolitanas, aglomerações urbanas e microrregiões eram unicamente do Estado membro, conforme o Artigo 25 da constituição Federal:

Art. 25 - Os Estados organizam-se e regem-se pelas Constituições e leis que adotarem, observados os princípios desta Constituição.

$\S 3^{\circ}$ Os Estados poderão, mediante lei complementar, instituir regiões metropolitanas, aglomerações urbanas e microrregiões, constituídas por agrupamentos de municípios limítrofes, para integrar a organização, o planejamento e a execução de funções públicas de interesse comum (Constituição Federal, 1988).

A partir do Estatuto da Metrópole, os municípios devem seguir os seguintes parâmetros, elencados no art. $2^{\circ}$ da lei federal, para a instituição de suas unidades territoriais, introduzindo os critérios adotados pelo IBGE, a saber:

Art. 2 - Para os efeitos desta Lei, consideram-se: 
I - aglomeração urbana: unidade territorial urbana constituída pelo agrupamento de 2 (dois) ou mais Municípios limítrofes, caracterizada por complementaridade funcional e integração das dinâmicas geográficas, ambientais, políticas e socioeconômicas;

II - função pública de interesse comum: política pública ou ação nela inserida cuja realização por parte de um Município, isoladamente, seja inviável ou cause impacto em Municípios limítrofes;

III - gestão plena: condição de região metropolitana ou de aglomeração urbana que possui:

a) formalização e delimitação mediante lei complementar estadual;

b) estrutura de governança interfederativa própria, nos termos do art. 80 desta Lei; e

c) plano de desenvolvimento urbano integrado aprovado mediante lei estadual;

IV - governança interfederativa: compartilhamento de responsabilidades e ações entre entes da Federação em termos de organização, planejamento e execução de funções públicas de interesse comum;

V - metrópole: espaço urbano com continuidade territorial que, em razão de sua população e relevância política e socioeconômica, tem influência nacional ou sobre uma região que configure, no mínimo, a área de influência de uma capital regional, conforme os critérios adotados pela Fundação Instituto Brasileiro de Geografia e Estatística - IBGE;

VI - plano de desenvolvimento urbano integrado: instrumento que estabelece, com base em processo permanente de planejamento, as diretrizes para o desenvolvimento urbano da região metropolitana ou da aglomeração urbana;

VII - região metropolitana: aglomeração urbana que configure uma metrópole.

Parágrafo único. Os critérios para a delimitação da região de influência de uma capital regional, previstos no inciso $\mathrm{V}$ do caput deste artigo considerarão os bens e serviços fornecidos pela cidade à região, abrangendo produtos industriais, educação, saúde, serviços bancários, comércio, empregos e outros itens pertinentes, e serão disponibilizados pelo IBGE na rede mundial de computadores (Lei $\mathrm{n}^{\circ}$ 13.089, 2015, Art. $2^{\circ}$ ).

A lei ainda acrescenta que no que couber, além das regiões metropolitanas e das aglomerações urbanas, as disposições aplicam-se às microrregiões instituídas pelos estados com fundamento em funções públicas de interesse comum com características predominantemente urbanas.

Hoshino e Moura (2015) comemoram o estabelecimento desses novos padrões mínimos, e acrescentam que essa exigência poderia ser ainda mais restritiva, porém está adequada à grande diversidade da rede urbana brasileira uma vez que em determinadas regiões de menor densidade de ocupação, os centros regionais detêm efetivamente a condição de metrópoles. Defendem que esse seria um passo para coibir a proliferação casuística da instituição de regiões metropolitanas, aglomerados urbanos e microrregiões, que implica em grandes obstáculos à promoção de ações nesse setor, sobretudo por parte do Governo Federal.

Nesse sentido, Ribeiro et al. (2015) lamentam que a lei não previu um meio de rever o quadro metropolitano oficial, previamente instituído pelos estados e considerado incoerente pelos autores. Sobre este ponto, a lei é ambígua, dando margem a interpretações divergentes. 
O Estatuto coloca que serão respeitadas as unidades territoriais urbanas criadas mediante lei complementar estadual anteriormente a entrada em vigor do Estatuto da Metrópole. Ao mesmo tempo, quando trata do apoio da união ao desenvolvimento urbano integrado, regula que a região metropolitana já instituída, mas que não atenda aos critérios explicitados, será enquadrada como aglomeração urbana para efeito das políticas públicas a cargo do Governo Federal, o que a excluiria de programas nacionais exclusivos para regiões metropolitanas.

Em 2017, o Brasil já tinha 74 regiões metropolitanas instituídas pelos estados. Santa Catarina é o expoente máximo da citada proliferação casuística de regiões metropolitanas, contando com 11 regiões metropolitanas que somadas ocupam 100\% do seu território. Como se pode ver no mapa da Figura 1, muitos outros estados com maior concentração populacional foram mais comedidos na instituição de suas RMs. Seguindo o critério estabelecido no Estatuto da Metrópole e levando-se em consideração que as regiões já instituídas seriam revistas, o resultado seria um mapa próximo ao apresentado na Figura 2.

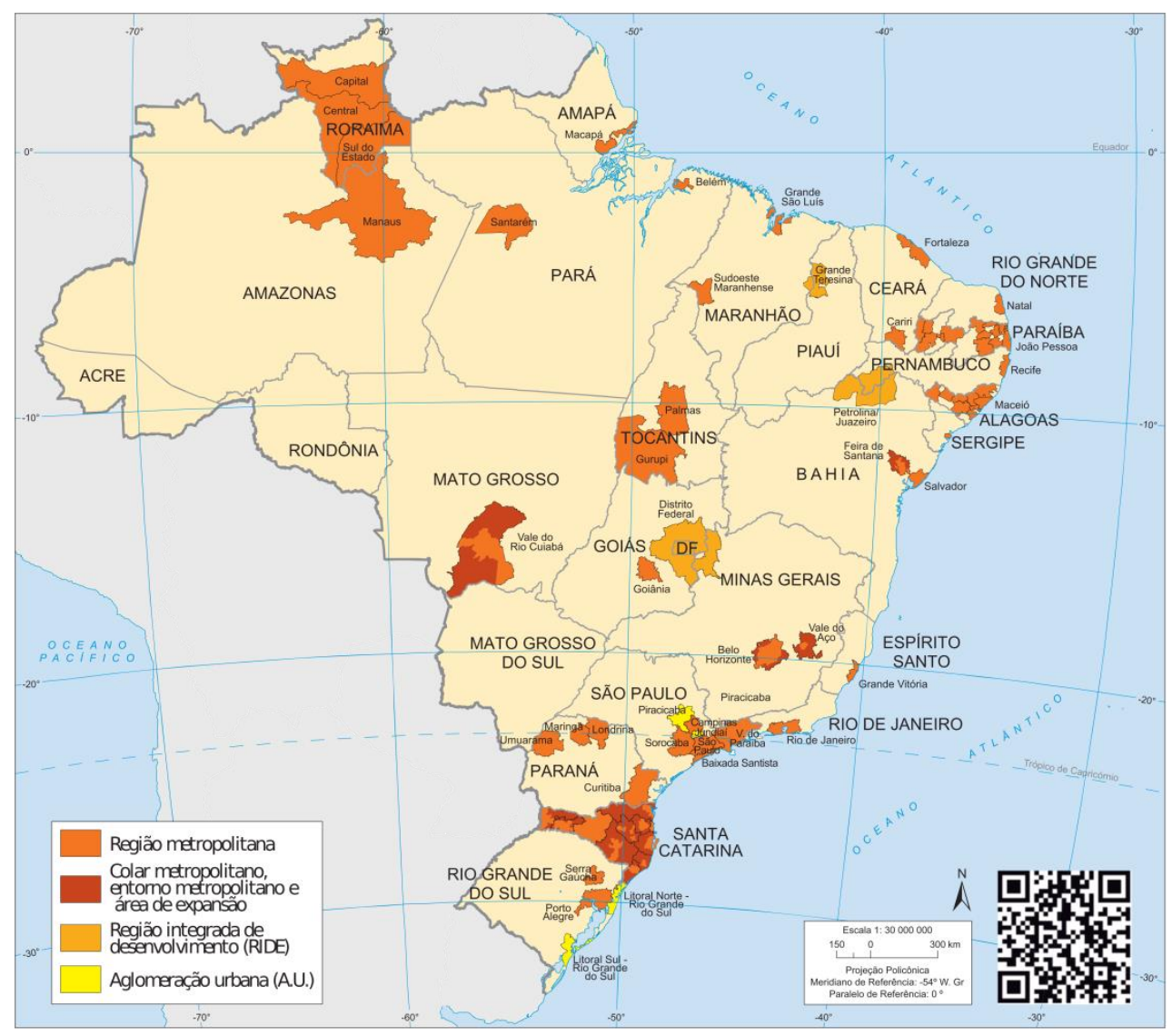

Figura 1: Mapa das Regiões Metropolitanas do Brasil Instituídas por Leis Estaduais Fonte: IBGE/ 2014 


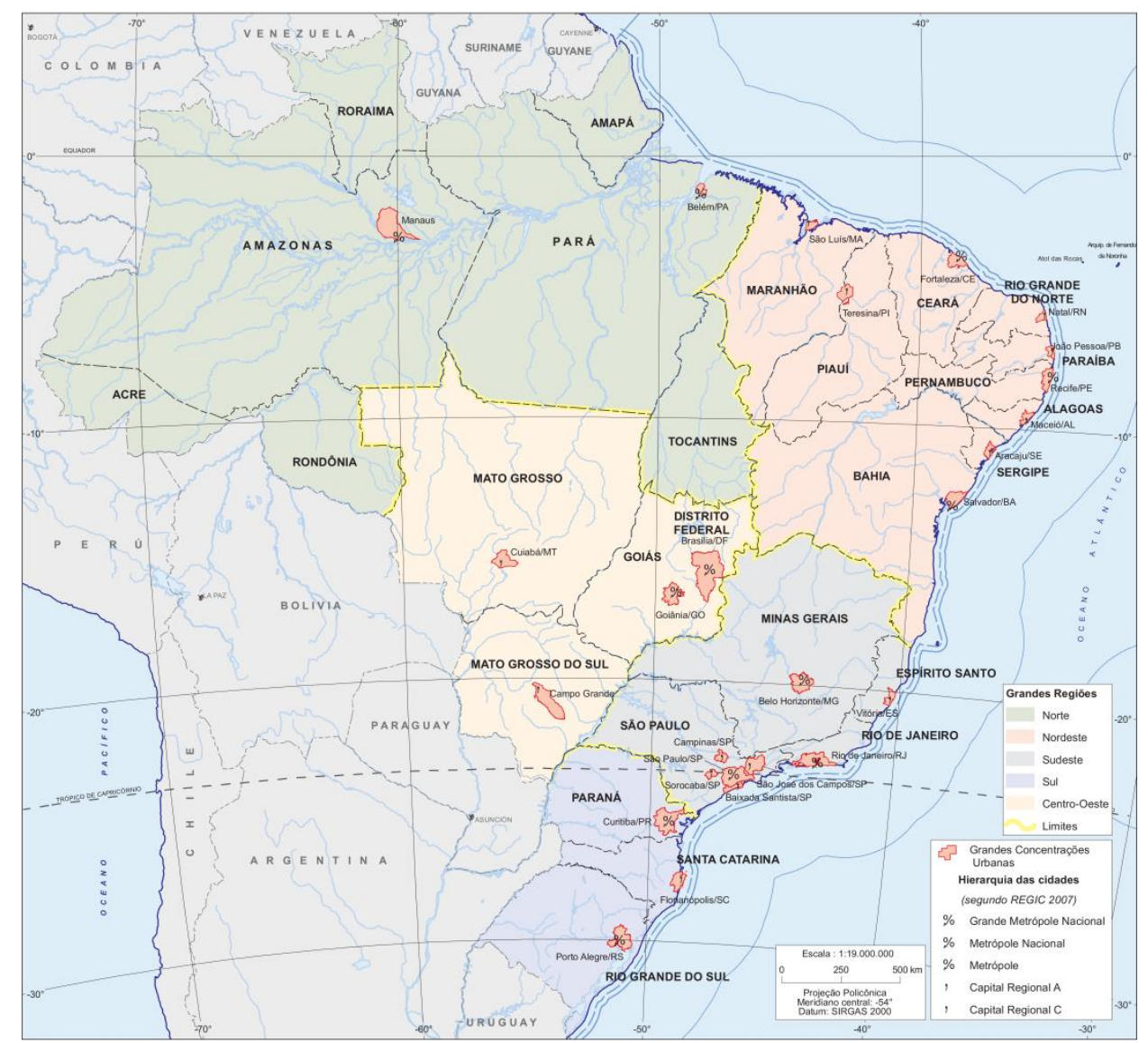

Figura 2: Mapa de Arranjos Populacionais e Concentrações Urbanas do Brasil Fonte: IBGE/ 2013

Os critérios utilizados pelo IBGE para definir os arranjos populacionais e concentrações urbanas foram comuns para todo o país, adotando-se uma abordagem que privilegiou elementos de integração, medidos pelos movimentos pendulares para trabalho e estudo e/ou pela contiguidade da mancha urbanizada. Como resultado, foram identificados 294 arranjos populacionais, que abrangem 55,7\% da população residente no Brasil, a partir dos quais foram definidas, por meio de cortes populacionais, as médias e grandes concentrações urbanas. Destacaram-se 26 grandes concentrações urbanas com mais de 750.000 habitantes, nas quais 12 têm papel metropolitano, número expressamente diferente das 74 regiões existentes atualmente instituídas pelas leis estaduais. 


\section{Santa Catarina e suas Instituições Regionais}

Siebert (2010) coloca que o estado de Santa Catarina é muito diversificado tanto em termos de suas condicionantes físico-naturais quanto nos seus diferentes processos históricos e políticos de ocupação. A diversidade catarinense, mostrou-se propícia a arranjos institucionais descentralizados, e fez do estado um laboratório de gestão colaborativa, planejamento e desenvolvimento de regiões a partir de instituições regionais como as Associações Municipal, os Fóruns de Desenvolvimento Regional, as Secretarias de Desenvolvimento Regional, e os Comitês de Gerenciamento de Bacias Hidrográficas.

Desde 1928 já era possível no estado a associação entre municípios para negociação de obras e serviços comuns. Todavia, é a partir da década de 1960 que há maior articulação entre os municípios em associações, reivindicando maior autonomia política e administrativa perante os níveis de governo nacional e estadual. O Governo passa, a partir de então, a estimular os programas de trabalho dessas entidades, que desenvolvem atividades de assessoramento técnico aos municípios, assumindo um papel fundamental para a operacionalização da gestão, principalmente para os municípios com menor poder de arrecadação e menos estruturados, que sofrem com a falta de recursos humanos para fazer frente às suas necessidades (VARGAS e THEIS, 2009).

Em 1992, o Governo do Estado, procurando incentivar a participação das Associações de Municípios no planejamento regional, estabelece convênios de cooperação técnica a partir da Secretaria de Estado do Planejamento e Fazenda. O objetivo principal desse foi a elaboração dos Planos Básico de Desenvolvimento Regional - PBDR e Plano Básico de Desenvolvimento Ecológico-Econômico - PBDEE, que são consideradas até hoje boas iniciativas no âmbito do planejamento regional e um marco na articulação entre níveis de governo.

Motivado pelo sucesso dessa experiência, em 1996 foi criado o Fórum Catarinense de Desenvolvimento (FORUMCAT), com fim de agregar os fóruns estabelecidos pelas Associações de Municípios. Vinculados ao FORUMCAT, mas funcionando de forma independente, foram criados "Fóruns de Desenvolvimento Regional" com a abrangência territorial de cada uma das Associações de Municípios, respeitando as articulações territoriais já existentes. Os Fóruns de Desenvolvimento Regional não chegaram a gerar planos regionais, apenas listas de prioridades regionais, e, não se sabe por consequência ou coincidência, desde 
que as Secretarias de Desenvolvimento Regional, foram instituídas pelo estado, em 2003, eles estão sem atividade relevante (SIEBERT, 2010).

As Secretarias de Desenvolvimento Regional (SDRs) continuam em atividade, embora tenham seu nome trocado em 2015 para Agências de Desenvolvimento Regionais (ADR). Pilares do projeto de descentralização administrativa do governo estadual, foram criadas em 2003, com o objetivo de combater a litoralização. A litoralização fora identificada no Plano de Governo Estadual como a causa do dramático esvaziando do campo, e responsável pelo inchando e deformação das cidades catarinenses. A criação das SDRs intencionou reequilibrar a população catarinense em todo o território (Siebert, 2010). Hoje há 36 Agências de Desenvolvimento Regionais que, por terem sido instituídas de maneira não coincidente com o recorte territorial das Associações de Município, gerou muitas críticas. Siebert (2010) coloca: “A proposta de reengenharia da estrutura governamental pretendia redistribuir as funções sem aumentar os cargos, mas, como era de se esperar, lamentavelmente acabou gerando um inchaço da máquina pública com cargos comissionados” (Sieber, p. 149, 2010). E acrescenta:

Apesar dessas questões, entendemos que a criação das Secretarias de Desenvolvimento Regional ainda pode ser considerada promissora, pois aproximou o governo estadual dos municípios, permitindo que as solicitações de verbas encaminhadas pelos prefeitos pudessem ser feitas na própria região, a um único secretário. As licitações de obras, anteriormente realizadas apenas na capital, passaram a ser feitas nas regiões, abrindo oportunidades para empresas locais. Além disso, foi ampliada a participação da sociedade civil na definição de políticas públicas, através do Conselho de Desenvolvimento Regional. (Sieber, p. 152, 2010)

Paralelamente a essas instituições e com a finalidade de enfrentar os problemas de enchentes, escassez e poluição da água bem como outros problemas socioambientais de maneira mais eficaz, a organização dos municípios em Comitês de Gerenciamento de Bacias Hidrográficas tornou-se prática comum no final do século. Hoje o estado tem 18 Comitês de Bacia vinculados ao Conselho Estadual de Recursos Hídricos e sua abrangência territorial, definida por critérios geográficos, tem se mostrado uma maneira coerente de lidar com o ordenamento regional. 


\section{Regiões Metropolitanas De Santa Catarina}

No contexto de uma política de descentralização histórica, as Regiões Metropolitanas de Santa Catarina também apresentam um cenário atípico em relação ao restante do país. $\mathrm{O}$ estado é o que tem o maior número de Regiões Metropolitanas instituídas no país, e ocupam $100 \%$ do território do estado.

A instituição de Regiões Metropolitanas, de acordo com o Artigo 25 da Constituição Federal (1989), ficou a cargo dos Estados membros. Esta atribuição foi regulamentada pelo Artigo 114 da Constituição do Estado de Santa Catarina, que coloca:

Art. 114 - O Estado, para integrar a organização, o planejamento e a execução das funções públicas de seu interesse e de Municípios limítrofes do mesmo complexo geoeconômico e social, poderá, mediante lei complementar, instituir:

I - regiões metropolitanas;

II - aglomerações urbanas;

III - microrregiões.

$\S 1^{\circ}$ - A instituição de região metropolitana se fará com base em avaliação do conjunto dos seguintes dados ou fatores, entre outros objetivamente apurados:

I - população, crescimento demográfico, grau de concentração e fluxos migratórios;

II - atividade econômica e perspectivas de desenvolvimento;

III - fatores de polarização;

IV - deficiência dos recursos públicos, em um ou mais Municípios, com implicação no desenvolvimento da região.

$\S 2^{\circ}$ - Não será criada microrregião integrada por menos de quatro por cento dos Municípios do Estado.

$\S 3^{\circ}$ - Os Municípios poderão criar associações, consórcios e entidades intermunicipais para a realização de ações, obras e serviços de interesse comum. (Constituição de Santa Catarina, 1989)

Percebe-se que os parâmetros elencados para a criação das Regiões Metropolitanas, embora coerentes, são subjetivos. O critério para a criação de Microrregiões é mais objetivo, uma vez que se determina que elas devem ser integradas por pelo menos de quatro por cento dos municípios do estado (pelo menos oito municípios em cada microrregião). No inciso IV do parágrafo $1^{\circ}$, quando é apontada a deficiência de recursos públicos como um motivador a criação da Região Metropolitana, vê-se um indício dos motivos da proliferação de RMs em Santa Catarina. Siebert (2010) coloca que a instituição das Regiões Metropolitanas em Santa Catarina também visou facilitar o acesso a verbas públicas em linhas de financiamento exclusivas para regiões metropolitanas.

Suprindo a necessidade de parâmetros mais objetivos para a instituição das Regiões Metropolitanas em Santa Catarina, em 1994 a Lei Complementar 104, de 1994, definiu que:

Art. $6^{0}$ Considerar-se-á "Região Metropolitana" o agrupamento de Municípios limítrofes a exigir planejamento integrado e ação conjunta, com união permanente de 
esforços para a execução das funções públicas de interesse comum dos entes públicos nela atuantes, e que apresentar, cumulativamente, as seguintes características:

I - densidade populacional bruta e/ou taxa de crescimento superiores à média do Estado, e população igual ou superior a 10\% (dez por cento) do Estado;

II - significativa conurbação;

III - nítida polarização, com funções urbanas e regionais com alto grau de diversidade e especialização;

IV - alto grau de integração socioeconômica.

Art. $7^{\circ}$ Considerar-se-á "Aglomeração Urbana" o agrupamento de Municípios limítrofes a exigir planejamento integrado e a recomendar ação coordenada dos entes públicos nele atuantes, orientada para o exercício das funções públicas de interesse comum, e que apresentar cumulativamente as seguintes características:

I - densidade populacional bruta e/ou taxa de crescimento superior à média do Estado, e população igual ou superior a $05 \%$ (cinco por cento) do Estado;

II - urbanização contínua entre Municípios ou manifesta tendência neste sentido;

III - polarização crescente, com tendência à especialização das funções urbanas ou regionais;

IV - forte integração socioeconômica.

(Lei Complementar 104, de 1994)

Seguindo os parâmetros desta Lei Complementar (104/1994) são instituídas as três primeiras Regiões Metropolitanas em Santa Catarina (Lei Complementar 162 de 1998) - as Regiões Metropolitanas de Florianópolis, do Vale do Itajaí e do Norte/ Nordeste Catarinense.

Em 1999, outra Lei Complementar (186/1999) altera o texto da LC 104/1994, flexibilizando os parâmetros para a instituição de regiões Metropolitanas conforme o seguinte:

Art. $1^{\circ} \mathrm{O}$ inciso I do art. $6^{\circ}$ da Lei Complementar no 104, de 04 de janeiro de 1994, passa a vigorar com a seguinte redação:

I - densidade populacional bruta e/ou taxa de crescimento superiores à média do Estado, e população igual ou superior a seis por cento do Estado;

Art. $2^{\circ} \mathrm{O}$ inciso I do artigo $7^{\circ}$ da Lei Complementar no 104, de 04 de janeiro de 1994, passa a vigorar com a seguinte redação:

I - densidade populacional bruta e/ou taxa de crescimento superiores à média do Estado, e população igual ou superior a três por cento do Estado;

(Lei Complementar 186, de 1999)

Entre 1999 e 2007 são instituídas mais quatro Regiões Metropolitanas: Foz do Rio Itajaí, Carbonífera, Tubarão e Chapecó. O processo de constituição das Regiões Metropolitanas é estancado quando são criadas as Secretarias de Desenvolvimento Regional. As Regiões Metropolitanas criadas até então são extintas.

Apenas em 2010 uma nova Lei Complementar ( $n^{\circ}$ 495) instituiu novamente as Regiões Metropolitanas de Florianópolis, do Vale do Itajaí, do Norte/Nordeste Catarinense, de Lages, da Foz do Rio Itajaí, Carbonífera e de Tubarão. No mesmo ano, a Lei Complementar $n^{\circ} 523$ amplia o número de Regiões Metropolitanas e instituí as do Alto Vale do Itajaí e de Chapecó. Em 2012 a Lei Complementar n 571 instituiu também as Regiões 
Metropolitanas do Extremo Oeste e do Contestado, totalizando as atuais 11 Regiões Metropolitanas instituídas em Santa Catarina.

Segue um quadro resumo das principais condicionantes legais do atual cenário metropolitano de Santa Catarina:

\begin{tabular}{|c|c|}
\hline Lei Complementar & Principais Condicionantes para o Cenário Metropolitano \\
\hline $\begin{array}{l}\text { Lei Complementar } \\
\text { 104/1994 } \\
\text { Alterada pela Lei } \\
\mathrm{n}^{\circ} 186 / 1999\end{array}$ & $\begin{array}{l}\text { Considerar-se-á Região Metropolitana quando a densidade populacional bruta e/ou } \\
\text { taxa de crescimento forem superiores à média do estado, e população igual ou } \\
\text { superior a } \mathbf{1 0 \%} \text { (dez por cento) do estado; } \\
\text { Considerar-se-á Aglomeração Urbana quando a densidade populacional bruta e/ou } \\
\text { taxa de crescimento superior à média do estado, e população igual ou superior a } \\
\mathbf{0 5 \%} \text { (cinco por cento) do estado; }\end{array}$ \\
\hline $\begin{array}{l}\text { Lei Complementar } \\
n^{\circ} 162 / 1998 \\
\text { REVOGADA } \\
\end{array}$ & $\begin{array}{l}\text { Ficam instituídas as Regiões Metropolitanas de Florianópolis, do Vale do Itajaí e do } \\
\text { Norte/ Nordeste Catarinense. }\end{array}$ \\
\hline \multirow{2}{*}{$\begin{array}{l}\text { Lei Complementar } \\
\text { n }^{\circ} 186 / 1999\end{array}$} & $\begin{array}{l}\text { Considerar-se-á Região Metropolitana quando a densidade populacional bruta e/ou } \\
\text { taxa de crescimento forem superiores à média do estado, e população igual ou } \\
\text { superior a seis por cento do estado; }\end{array}$ \\
\hline & $\begin{array}{l}\text { Considerar-se-á Aglomeração Urbana quando a densidade populacional bruta e/ou } \\
\text { taxa de crescimento superior à média do estado, e população igual ou superior a } \\
\text { três por cento do estado; }\end{array}$ \\
\hline $\begin{array}{l}\text { Lei Complementar } \\
\mathrm{n}^{\mathbf{o}} 221 / 2002 \\
\text { REVOGADA } \\
\end{array}$ & $\begin{array}{l}\text { Ficam instituídas as Regiões Metropolitanas da Foz do Rio Itajaí, Carbonífera e } \\
\text { Tubarão. }\end{array}$ \\
\hline $\begin{array}{l}\text { Lei Complementar } \\
\mathrm{n}^{\mathbf{o}} 377 / 2007 \\
\text { REVOGADA } \\
\end{array}$ & Fica instituída a Região Metropolitana de Chapecó. \\
\hline $\begin{array}{l}\text { Lei Complementar } \\
n^{\circ} 3812007 \\
\text { Alterada pela Lei } \\
\mathrm{n}^{\circ} 16.795 / 2015 \\
\end{array}$ & $\begin{array}{l}\text { Cria novas Secretarias de Desenvolvimento Regional e revogou as Leis } \\
\text { Complementares 162/1998 e 221/2002, que instituíam as Regiões Metropolitanas. }\end{array}$ \\
\hline $\begin{array}{l}\text { Lei Complementar } \\
\mathrm{n}^{\circ} 495 / 2010\end{array}$ & $\begin{array}{l}\text { Ficam instituídas as Regiões Metropolitanas de Florianópolis, do Vale do Itajaí, do } \\
\text { Norte/Nordeste Catarinense, de Lages, da Foz do Rio Itajaí, Carbonífera e de } \\
\text { Tubarão. }\end{array}$ \\
\hline $\begin{array}{l}\text { Lei Complementar } \\
\mathrm{n}^{\circ} 523 / 2010\end{array}$ & Ficam instituídasas Regiões Metropolitanas do Alto Vale do Itajaí e de Chapecó. \\
\hline $\begin{array}{l}\text { Lei Complementar } \\
\mathrm{n}^{\circ} 571 / 2012\end{array}$ & Ficam instituídas as Regiões Metropolitanas do Extremo Oeste e do Contestado. \\
\hline $\begin{array}{l}\text { Lei Complementar } \\
\text { nº } 16.795 / 2015\end{array}$ & $\begin{array}{l}\text { Ficam as Secretarias de Estado de Desenvolvimento Regional transformadas em } \\
\text { Agências de Desenvolvimento Regional }\end{array}$ \\
\hline
\end{tabular}

Quadro 1: Mapa de Arranjos Populacionais e Concentrações Urbanas do Brasil Fonte: Leis Complementares SC

Chama a atenção que a alteração na LC 186/1999, que diminui as exigências para conformação de Regiões Metropolitanas em Santa Catarina, não altera o texto no que diz respeito à necessidade de a região apresentar "significativa conurbação". Essa característica mostra-se mais limitadora do que as exigências relativas aos novos índices populacionais mínimos. 
A comprovação da "significativa conurbação" citada, todavia, não é inequívoca. No estado há algumas áreas metropolitanas com significativa conurbação, porém outras não apresentam essa característica. Pode-se chamar de áreas conurbadas "verídicas" aquelas cuja mancha urbana dos municípios efetivamente se confunde. Em contrapartida, pode-se chamar de "fictícias", as áreas que acontecem quando a legislação municipal define o perímetro urbano legal além da mancha urbana real, algumas vezes unindo o perímetro urbano de municípios limítrofes sem necessariamente que esta urbanização exista de fato.

As figuras que seguem buscam expressar a conurbação do estado através de características que podem ser entendidas como medidas de urbanização. A partir destas imagens (Figuras 3, 4, 5 e 6) é possível apreender que há áreas de conurbação onde a mancha de um município encontra com a do outro, configurando uma só grande área de urbanização, mas em outros momentos isso não ocorre.

A Figura 3 mostra o perímetro urbano legal dos municípios, demonstrando uma possível conurbação fictícia. A Figura 4 mostra a codificação de características urbanas (IBGE, 2010), onde são respeitadas as divisões políticos administrativas para a criação dos setores. Esta representação, bem como a expressa na Figura 3, também é limitada, pois na definição dos setores não é considerada a mancha urbana existente. Conforme GUARDA (2010), a criação dos setores objetiva critérios quantitativos funcionais e logísticos, sendo buscados elementos geográficos de fácil identificação em campo como limite de setores. Com isto há uma distribuição das Características Urbanas pelo setor de forma ilusória, podendo resultar em uma densidade fictícia. Percebe-se nas Figuras 3 e 4 que o mapa do perímetro urbano legal se assemelha ao mapa da Codificação das Características Urbanas.

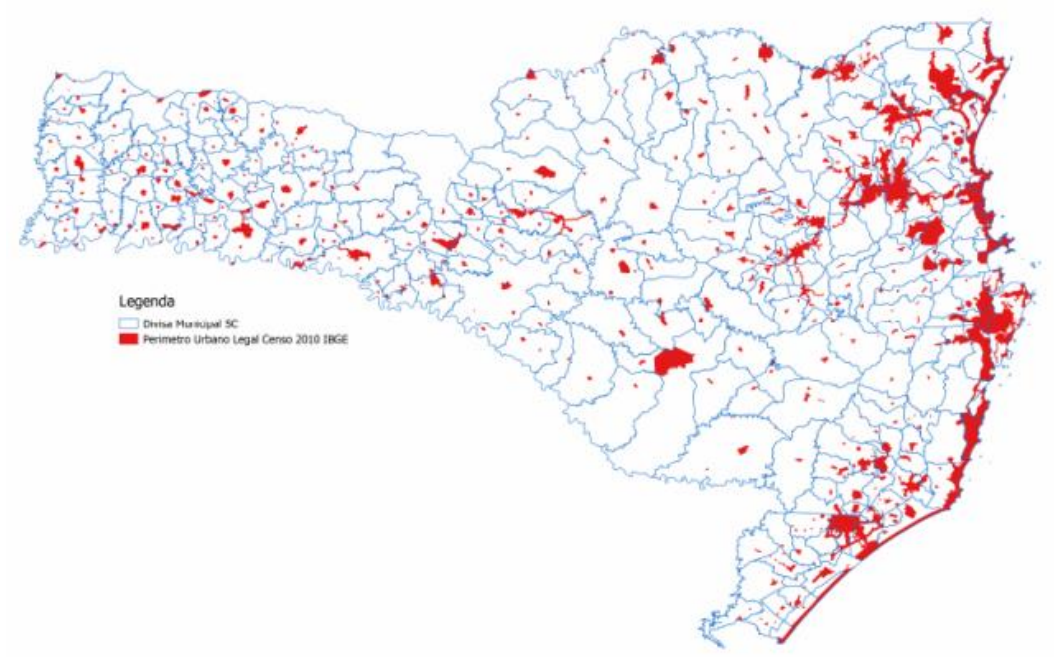

Figura 3 - Perímetro Urbano Legal 


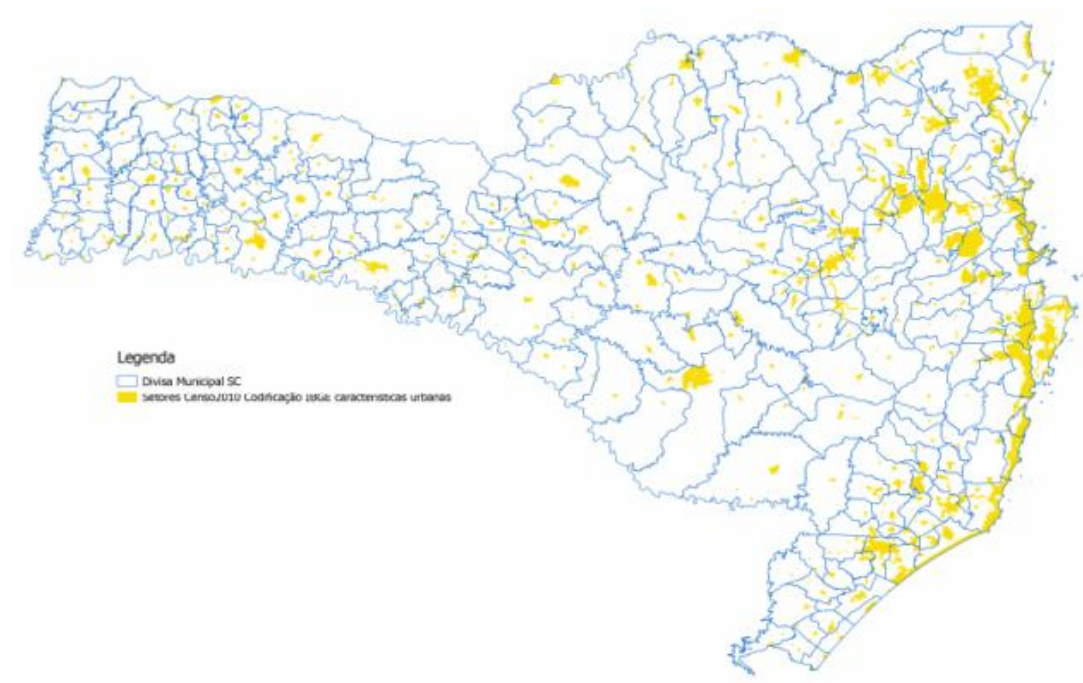

Figura 4 - Codificação de Características Urbanas

Fonte:Dados IBGE/CENSO2010 Produzido pelos autores / 2017

A Figura 5, a seguir, mostra a densidade predial de 600 edificações ou endereços por $\mathrm{km}^{2}$, informação retirada do CNEFE - Cadastro Nacional de Endereços para Fins Estatísticos no setor, independente do código de situação do setor, e respeitando a divisão político administrativa. Enquanto a Figura 6 também mostra a densidade predial de 600 edificações ou endereços por $\mathrm{km}^{2}$, retirada do CNEFE, mas com a diferença da densidade ser aplicada em células de 1000 por 1000 metros e células de 250 por 250 metros, sendo independente das divisões político administrativas. Essas duas figuras já expressam uma redução considerável nas áreas conurbadas do Estado de Santa Catarina em relação as variáveis apresentadas nas Figuras 3 e 4.

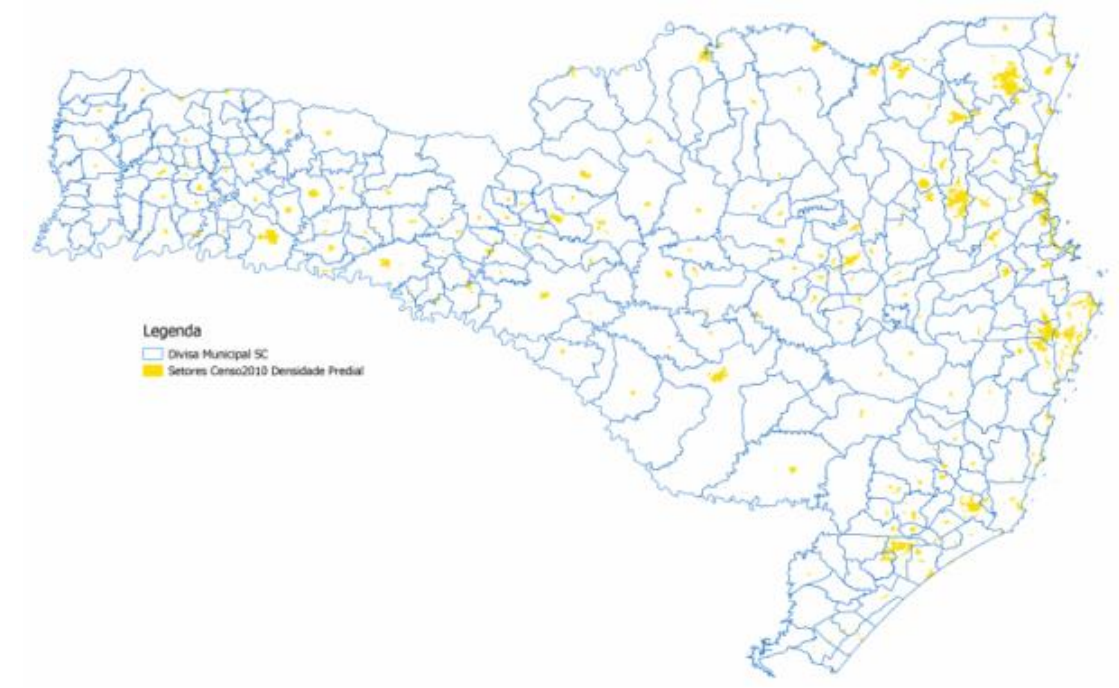

Figura 5 - Densidade Predial dos Setores Censitários 


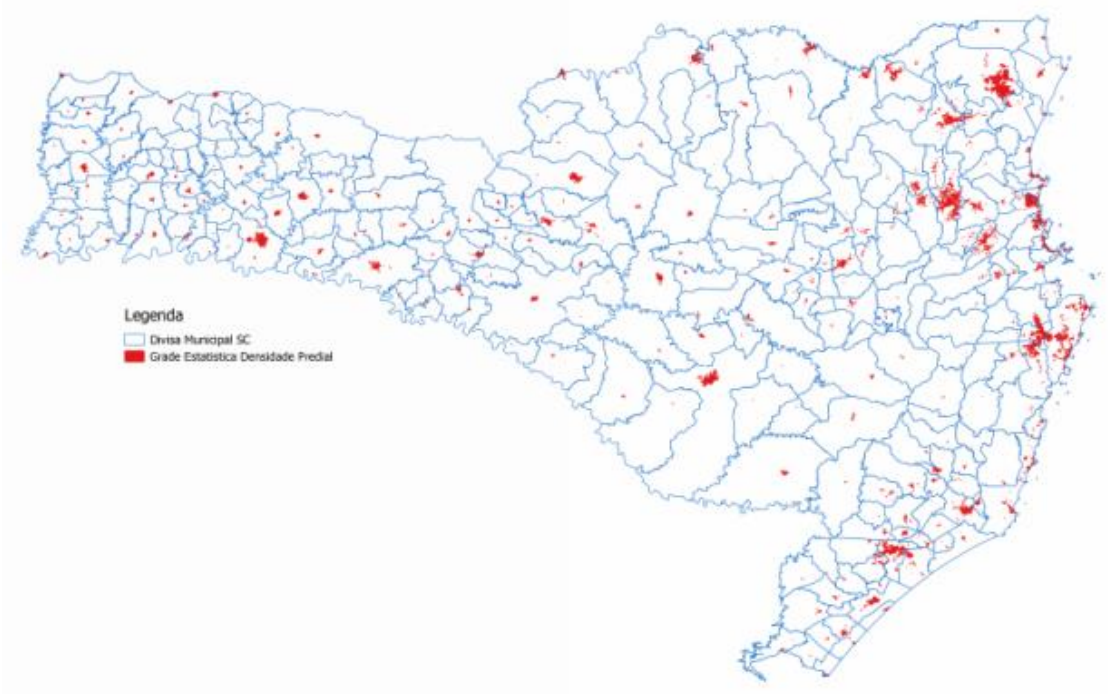

Figura 6 - Densidade Predial por Grade Estatística

Fonte: Dados IBGE/CENSO2010/CNEFE, Produzido pelos autores / 2017

Percebe-se que, a despeito dos parâmetros regulamentados para a instituição de Regiões Metropolitanas no estado, na prática a "significativa coburnação" não está sendo prérequisitada, fosse assim o estado não teria nenhuma das suas atuais 11 Regiões Metropolitanas configuradas como estão, pois nenhuma delas apresenta "significativa conurbação" entre todos os municípios incluídos, nem mesmo considerando a conurbação possivelmente fictícia dos mapas das Figuras 3 e 4.

Siebert (2010) explica que o modelo proposto para as regiões metropolitanas catarinenses diferiu do que foi adotado no resto do País, pois em vez dessas regiões metropolitanas serem constituídas apenas pelo município polo e área conurbada, elas englobam também as áreas rurais e os pequenos municípios na denominada área de expansão metropolitana. Segundo a autora o objetivo desse modelo foi promover o desenvolvimento regional equilibrado, evitando a concentração populacional e de recursos.

Apesar da existência legal das regiões metropolitanas, em Santa Catarina elas mostram-se em termos propositivos e organizacionais pouco operantes. Até o momento não geraram nenhum plano regional mesmo com a exigência do Estatuto da Metrópole da realização do PDUI. A única Região Metropolitana que abriu edital para realizar o Plano de Desenvolvimento Urbano Integrado foi a Região Metropolitana da Grande Florianópolis. Ainda assim, o edital aberto em meados de 2016 foi cancelado alguns meses depois por inconsistências levantadas pelos consórcios participantes. Até o momento nenhum outro 
edital visando a elaboração do Plano de Desenvolvimento Urbano Integrado foi aberto, conforme verificado no site de compras do governo do estado.

Abstendo-se de entrar na complicada averiguação da conurbação, o Estatuto da Metrópole, conforme já citado, utilizou-se da expressão “espaço urbano com continuidade territorial" que configure no mínimo a área de influência de uma capital regional segundo critérios do IBGE, como pré-requisito mínimo para a instituição das Regiões Metropolitanas. Conforme vê-se na Figura 7, em Santa Catarina seria possível a instituição de cinco Regiões Metropolitanas, sendo elas Florianópolis, Joinville, Blumenau, Chapecó e Criciúma, ou seja, as cidades com área de influência de Capital Regional segundo o IBGE. Esses padrões mínimos mostram-se bastante abrangentes, uma vez que até Criciúma, cidade com população estimada de 211.369 habitantes, segundo o IBGE, poderá ser considerada polo de uma região metropolitana.

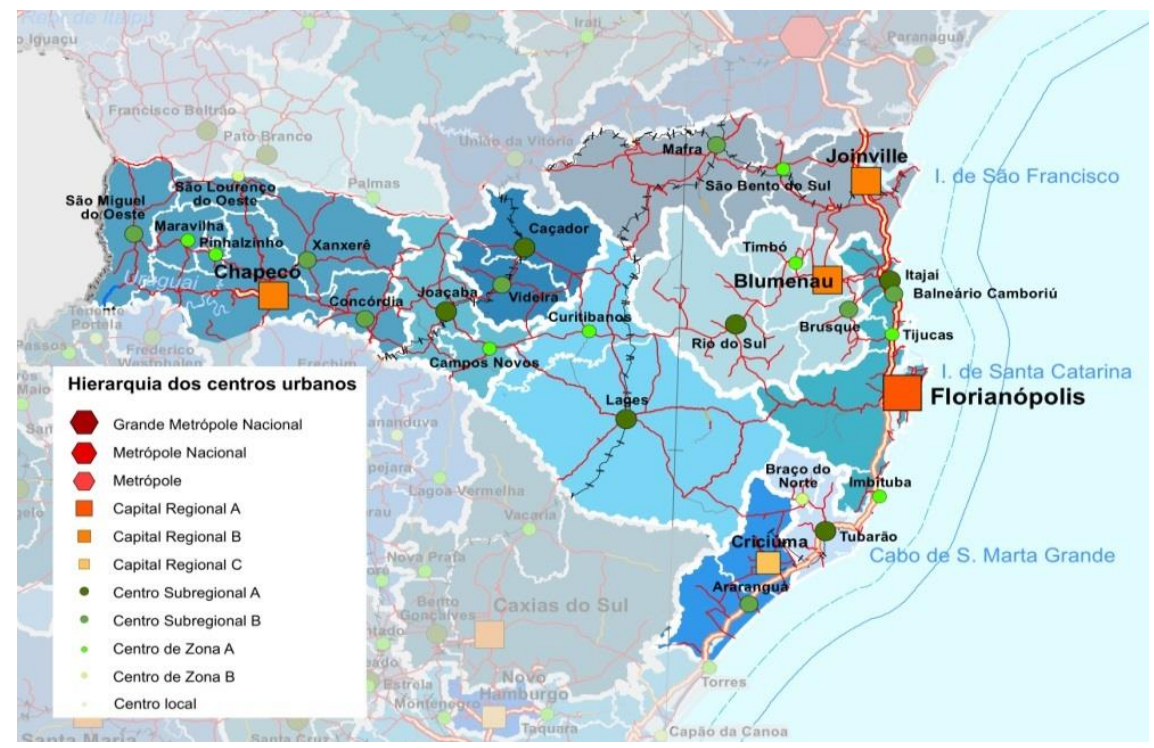

Figura 7 - Mapa de Hierarquia dos Centros Urbanos Fonte: IBGE/2013

Dessa maneira, a utilização dos critérios estabelecidos pelo IBGE mostra-se uma alternativa mais fiel à realidade do estado, na medida em que apresenta as descontinuidades existentes na mancha urbana, conforme se vê no mapa dos Arranjos Populacionais do IBGE, Figura 8. Enquanto o mapa das atuais regiões instituídas pelo estado de Santa Catarina, Figura 9 representa uma homogeneidade irreal. 


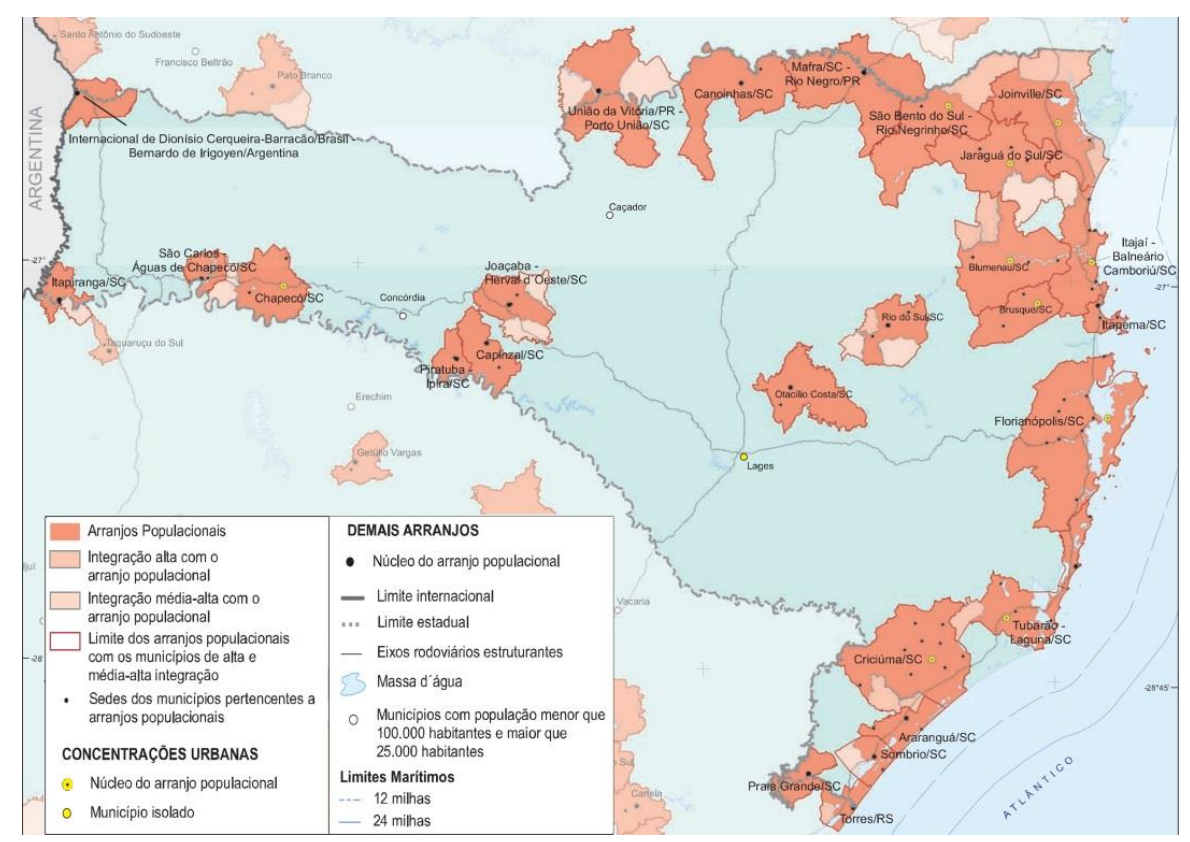

Figura 8: Mapa de Arranjos Populacionais e Concentrações Urbanas de Santa Catarina Fonte: IBGE/ 2010

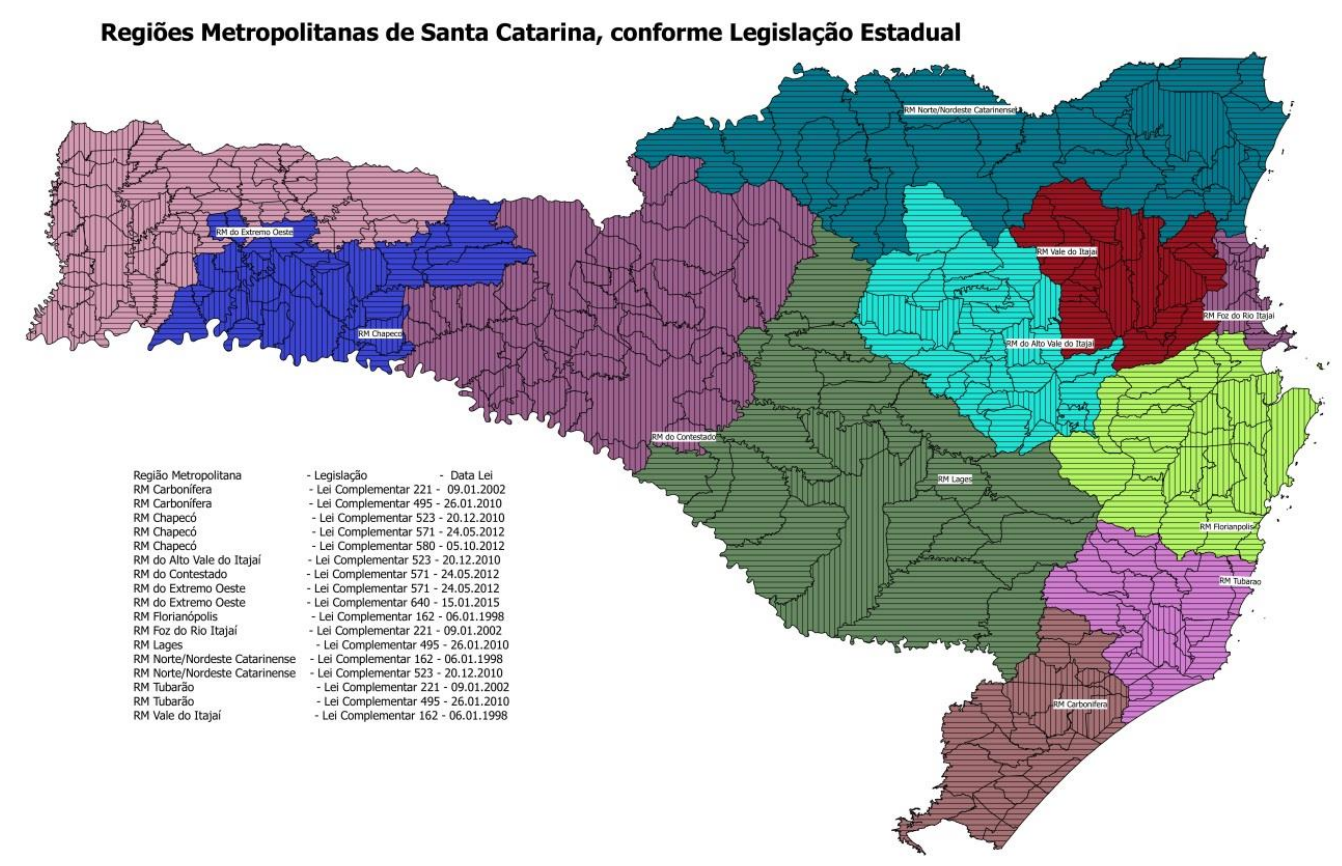

Figura 9: Mapa das Regiões Metropolitanas de Santa Catarina Instituídas por Leis Estaduais Fonte: Produzido pelos autores / 2017

\section{Considerações Finais}

Franzoni e Hoshino (2015) apontam que ao longo da história político-institucional brasileira percebe-se que a forma de agenciamento da escala metropolitana variou de acordo com o modelo de desenvolvimento econômico e alinhamentos conjunturais, não 
necessariamente atentos à justiça socioespacial como valor finalístico. Com isso em vista, o Estatuto da Metrópole mostra-se, apesar de suas limitações, uma ferramenta importante para facilitar o ordenamento a partir do estabelecimento de padrões e nomenclaturas nacionais.

Embora o enquadramento como Região Metropolitana não sirva para todas as unidades territoriais, Planos de Desenvolvimento Regionais são bem-vindos para auxiliar municípios configurados como uma microrregião a ordenar suas intenções e resolver questões comuns de meio ambiente, mobilidade, saneamento, etc. Tais planos seriam benéficos especialmente para os municípios com áreas rurais, uma vez que estas foram excluídas na descrição e definição das áreas para a aplicação do Estatuto da Metrópole. Essas áreas de abrangência intermunicipal, com características coerentes em termos ambientais, políticas, e culturais não necessariamente urbana e nem necessariamente densificadas, seriam beneficiadas por uma legislação própria para ordenamento regional, uma vez que hoje muitos municípios pequenos nem possuem Plano Diretor.

A Subcomissão de Governança Metropolitana da Câmara dos Deputados explica que “as microrregiões não devem ser definidas como sendo territórios predominantemente urbanos, eis que tais unidades territoriais são caracterizadas, de modo geral, por agrupamento de municípios sem qualquer conurbação e com extenso território rural" (Câmara Dos Deputados, 2016, p.2). O vício de linguagem, que infelizmente transcende o texto, ressalta que o território rural é efetivamente esquecido no planejamento regional e no texto do Estatuto da Metrópole, onde até o instrumento principal da lei, o chamado Plano de Desenvolvimento Urbano Integrado - PDUI, deveria ter seu nome substituído por Plano de Desenvolvimento Regional Integrado - PDRI, como bem apontaram os deputados.

Hoje parece haver um consenso de que a adoção de critérios meramente políticos na instituição de Regiões Metropolitanas é prejudicial ao planejamento do território interfederativo. Sob o discurso da integração e o desenvolvimento regional, há uma pasteurização das unidades territoriais que dificulta sua gestão e a eleição de prioridades, uma vez que áreas com diferentes características precisam de tratamentos e legislações diferenciadas.

Mencio e Zioni (2017) em seu texto elencam as interpretações jurídicas que defendem a competência do Estado membro e as interpretações jurídicas que defendem a competência do IBGE na caracterização das metrópoles e das regiões metropolitanas. No que tange a prática do planejamento regional integrado e a busca de espaços melhores para se viver, é fato que o Estatuto precisa ser colocado em prática e os Planos de Desenvolvimento Integrados 
realizados. Assim, apresenta-se como a melhor solução que sejam estabelecidos conceitos bem delimitados e detalhados, para não haver possibilidade de esquivas, como acontece em incontáveis leis que nunca saem do papel.

Nesse caso, dar o nome certo aos tipos de arranjos territoriais não é mero capricho. Conclui-se que adotar os critérios estabelecidos pelo IBGE apresenta-se como um bom ponto de partida, ainda que a conceituação das metrópoles e regiões metropolitanas pudesse ser ainda mais rigorosa. Esse rigor não deve esquecer, contudo, a necessidade de planejamento para áreas que não configuram metrópoles e/ou regiões metropolitanas através de um Plano de Desenvolvimento Regional Integrado.

É necessário que os planos regionais existam, e que sejam particulares para cada arranjo territorial, levando em consideração suas limitações em seus preceitos legais. Só assim os estatutos, na definição de suas diretrizes, poderão ter coerência com as carências e potencialidades do objeto a ser regulamentado e alcançar a efetividade.

\section{Referências Bibliográficas}

BOEIRA, Sérgio Luiz. Desenvolvimento Urbano e Crise de Paradigmas: o caso da Região de Florianópolis. PerCursos, Florianópolis, v.6, n.2, 2004.

BRASIL. Constituição da República Federativa do Brasil de 1988. Planalto, Brasília, 1988.

Lei $\mathrm{n}^{\circ} 13.089$, de 12 de janeiro de 2015. Institui o Estatuto da Metrópole, altera a Lei n⿳ 10.257, de 10 de julho de 2001, e dá outras providências. Planalto, Brasília, 2015. CÂMARA DOS DEPUTADOS. Propostas para revisão e aperfeiçoamento do Estatuto da Metrópole. Comissão de Desenvolvimento Urbano, Subcomissão Especial de Governança Metropolitana. Brasília, 2016.

DE SÁ, Rafael Amorim Martins, et al. Estatuto da Metrópole: a governança interfederativa. Urbe. Revista Brasileira de Gestão Urbana, Curitiba, v.9, n.2, 2017.

FRANZONI, Julia Ávila; HOSHINO, Thiago de Azevedo Pinheiro. Da urbanização periférica ao direito à metrópole: a lei $13089 / 2015$ no reescalonamento da política urbana. Revista Brasileira de Direito Urbanístico- RBDU, Belo Horizonte, v. 1, n. 1, jul/dez 2015.

GUARDA, Antonio. Avaliação Metodológica para Determinar a Dinamicidade de Dados do Censo Demográfico. 193 f. Dissertação (mestrado) - Universidade Federal de Santa Catarina, Centro Tecnológico, Programa de Pós Graduação em Engenharia Civil. Florianópolis, 2010.

HARVEY, David. A produção Capitalista do Espaço. 2. ed. São Paulo: Annablume, 2006. HOSHINO, T. A. P; MOURA, R. Estatuto da metrópole: enfim, aprovado! Mas o que oferece à metropolização brasileira? Disponível em: <http://www.observatoriodasmetropoles.net/download/estatuto_metropole_artigo_rosa.pdf>. Acesso em: 09 jun. 2017.

INSTITUTO BRASILEIRO DE GEOGRAFIA E ESTATÍSTICA - IBGE. Regiões de Influência das Cidades: 2007/IBGE. Rio de Janeiro: IBGE, 2008. 
Arranjos Populacionais e Concentrações Urbanas no Brasil. Rio de Janeiro: IBGE, 2. Ed., 2016.

MARICATO, Ermínia. Metrópoles desgovernadas. Dossiê São Paulo, Hoje, São Paulo, v.25 n.71, Jan./Apr. 2011.

MENCIO, M.; ZIONI, S. A caracterização das Regiões Metropolitanas e Aglomerações Urbanas pelo IBGE: Limites e Avanços do Estatuto da Metrópole. Disponível em: <http://anpur.org.br/xviienanpur/principal/publicacoes/XVII.ENANPUR_Anais/ST_Sessoes_ Tematicas/ST\%202/ST\%202.2/ST\%202.2-02.pdf> Acesso em: 09 jun. 2017.

NETO, João Mendes da Rocha; ALVES, Adriana Melo. Disjunções legais e institucionais da política metropolitana e da politica nacional de desenvolvimento regional. EURE Revista Latinoamericana de Estudios Urbano-Regionales, Santiago, v.42, n.127, 2016.

REIS FILHO, Nestor Goulart. Notas sobre urbanização dispersa e novas formas de tecido urbano. São Paulo: Via das Artes, 2006.

RIBEIRO, L. C. Q.; SANTOS JÚNIOR, O. A.; RODRIGUES, J. M. Estatuto da Metrópole: avanços, limites e desafios. Disponível em: $<$ http://www.observatoriodasmetropoles.net/index.php?option=com_k2\&view=item\&id=114 8:estatuto-da-metr\%C3\%B3pole-avan\%C3\%A7os-limites-e-

desafios\&Itemid=180\&lang=en\#>. Acesso em: 09 jun. 2017.

SANTA CATARINA, Constituição do Estado de Santa Catarina de 1989. Assembleia Legislativa de Santa Catarina, Florianópolis, Edição atualizada em agosto de 2017, 2017.

. Lei Complementar n ${ }^{\circ} 104$, de 04 de janeiro de 1994. Dispõe Sobre os Princípios da Regionalização do Estado e Adota Outras Providências. Assembleia Legislativa de Santa Catarina, Florianópolis, 1994.

Lei Complementar $\mathrm{n}^{\mathbf{0}} 162$, de 06 de janeiro de 1998. Institui as Regiões Metropolitanas de Florianópolis, do Vale do Itajaí e do Norte/Nordeste Catarinense e Estabelece Outras Providências. Assembleia Legislativa de Santa Catarina, Florianópolis, 1998.

Lei Complementar $n^{\circ} 186$, de 20 de novembro de 1999. Altera a redação da Lei Complementar $n^{0}$ 104, de 04 de janeiro de 1994, que dispõe sobre a regionalização do Estado. Assembleia Legislativa de Santa Catarina, Florianópolis, 1999.

Lei Complementar $\mathrm{n}^{\mathbf{0}}$ 221, de 09 de janeiro de 2002. Institui as Regiões

Metropolitanas aa Foz Do Rio Itajaí, Carbonífera, Tubarão e Estabelece Outras Providências. Assembleia Legislativa de Santa Catarina, Florianópolis, 2002.

Lei Complemenar Promulgada $n^{\circ} 377$, de 17 de abril de 2007. Institui a Região Metropolitana de Chapecó e Estabelece Outras Providências. Assembleia Legislativa de Santa Catarina, Florianópolis, 2007.

. Lei Complementar $n^{\circ} 381$, de 07 de maio de 2007. Dispõe sobre o modelo de gestão e a estrutura organizacional da Administração Pública Estadual. Assembleia Legislativa de Santa Catarina, Florianópolis, 2007.

Lei Complementar $\mathrm{n}^{\mathbf{0}}$ 495, de 26 de janeiro de 2010. Institui as Regiões Metropolitanas de Florianópolis, do Vale do Itajaí, do Alto Vale do Itajaí, do Norte/Nordeste Catarinense, de Lages, da Foz do Rio Itajaí, Carbonífera, de Tubarão, de Chapecó, do Extremo Oeste e do Contestado. Assembleia Legislativa de Santa Catarina, Florianópolis, 2010.

Lei Complementar $n^{\circ}$ 523, de 17 de dezembro de 2010. Altera Dispositivos da Lei Complementar $n^{\circ}$ 495, de 2010, que institui as Regiões Metropolitanas. Assembleia Legislativa de Santa Catarina, Florianópolis, 2010.

Lei Complementar $n^{\circ}$ 571, de 24 de maio de 2012. Institui as Regiões Metropolitanas do Extremo Oeste e do Contestado e altera a Lei Complementar $n^{\circ} 495$, 
de 2010, que institui as Regiões Metropolitanas de Florianópolis, do Vale do Itajaí, do Alto Vale do Itajaí, do Norte/Nordeste Catarinense, de Lages, da Foz do Rio Itajaí, Carbonífera, de Tubarão e de Chapecó. Assembleia Legislativa de Santa Catarina, Florianópolis, 2012. . Lei $\mathrm{n}^{\circ} 16.795$, de 16 de dezembro de 2015. Dispõe sobre a transformação das Secretarias de Estado de Desenvolvimento Regional em Agências de Desenvolvimento Regional, extingue cargos e estabelece outras providências. Assembleia Legislativa de Santa Catarina, Florianópolis, 2015.

SANTOS, Milton. A Urbanização Brasileira. 5. ed. 2. reimp. São Paulo: Editora da Universidade de São Paulo, 2009.

SIEBERT, Claudia. Arranjos Institucionais e Trajetória do Planejamento Territorial em Santa Catarina. Revista Paranaense de Desenvolvimento, Curitiba, n.119, jul./dez. 2010.

VARGAS, Diego Boelhke, THEIS , Ivo Marcos. Dilemas do Planejamento Nacional e Estadual: A Experiência das Secretarias de Desenvolvimento Regional de Santa Catarina. Cadernos de Economia da Unochapecó, Chapecó, v. 13, n. 24, Jun. 2009.

Recebido em 20 de dezembro de 2017. Aceito em 26 de fevereiro de 2018. 